\title{
Cardiac Metabolism in Sepsis
}

\author{
Satoshi Kawaguchi ${ }^{1}$ and Motoi Okada ${ }^{2, *(D)}$ \\ 1 Department of Anatomy, Cell Biology and Physiology, Indiana University School of Medicine, \\ Bloomington, IN 46202, USA; s-kawa@asahikawa-med.ac.jp \\ 2 Department of Emergency Medicine, Asahikawa Medical University, Asahikawa 078-8510, Japan \\ * Correspondence: motoy@asahikawa-med.ac.jp; Tel.: +81-166-68-2852
}

check for updates

Citation: Kawaguchi, S.; Okada, M. Cardiac Metabolism in Sepsis. Metabolites 2021, 11, 846. https:// doi.org/10.3390/metabo11120846

Academic Editor: Tatsuya Iso

Received: 14 November 2021

Accepted: 2 December 2021

Published: 6 December 2021

Publisher's Note: MDPI stays neutral with regard to jurisdictional claims in published maps and institutional affiliations.

Copyright: (c) 2021 by the authors. Licensee MDPI, Basel, Switzerland. This article is an open access article distributed under the terms and conditions of the Creative Commons Attribution (CC BY) license (https:/ / creativecommons.org/licenses/by/ $4.0 /)$.

\begin{abstract}
The mechanism of sepsis-induced cardiac dysfunction is believed to be different from that of myocardial ischemia. In sepsis, chemical mediators, such as endotoxins, cytokines, and nitric oxide, cause metabolic abnormalities, mitochondrial dysfunction, and downregulation of $\beta$-adrenergic receptors. These factors inhibit the production of ATP, essential for myocardial energy metabolism, resulting in cardiac dysfunction. This review focuses on the metabolic changes in sepsis, particularly in the heart. In addition to managing inflammation, interventions focusing on metabolism may be a new therapeutic strategy for cardiac dysfunction due to sepsis.
\end{abstract}

Keywords: sepsis; SICM; $\beta$-adrenergic receptor; metabolic switch; ATP

\section{Introduction}

Sepsis, defined as life-threatening organ dysfunction caused by a dysregulated host response to infection, is one of the leading causes of death worldwide [1]. Recent research estimates that more than 19.4 million people develop severe sepsis, and 5 million die each year [2]. Therefore, there is an urgent need to understand this disease and find novel strategies for sepsis therapy.

In sepsis-induced organ dysfunction, the most serious complication is cardiac dysfunction, called sepsis-induced cardiomyopathy (SICM) or sepsis-related myocardial dysfunction. The mortality in patients with septic shock is more than $40 \%$, whereas it is $10 \%$ in patients without shock [1]. According to some studies, the prevalence of SICM ranges from $10 \%$ to $70 \%$ in patients with severe sepsis [3,4]. In the state of SICM, a high level of circulating catecholamines downregulates the response of the $\beta$-adrenergic receptor $(\beta \mathrm{AR})$ in cardiomyocytes, blunting the contractile response of cardiomyocytes to catecholamines [5-7]. This means that vasopressors to maintain blood pressure do not work for SICM treatment. Although cardiovascular abnormalities in sepsis have been known since the 1950s [8], Parker et al. reported that intrinsic myocardial dysfunction, with an increased volume and a decreased ejection fraction, in patients with sepsis is reversible [9]. Furthermore, these functional changes in the left ventricle were observed 7-10 days from the onset in survivors, whereas they were less profound in non-survivors $[9,10]$. This suggests that cardiac dysfunction in sepsis is a compensatory mechanism to confer protection from the damage. Following the report, some clinical studies have identified that cardiac dysfunction has reversible systolic and diastolic functions in both the left and right ventricles during sepsis [11,12]. However, recent studies have failed to demonstrate the protective role of cardiac dysfunction [13-15]. On the contrary, some clinical researchers suggested that cardiac dysfunction in sepsis is strongly associated with mortality [16-19]. These different conclusions might result from the complexity of the disease, patient characteristics, methods of diagnosis, and disease access. Notably, the important and interesting characteristics of cardiac dysfunction in sepsis include its reversibility. Despite the advances in our understanding of pathophysiology of sepsis through numerous animal and clinical research studies, the mechanism of SICM remains unclear. 
To the best of our knowledge, the mechanism of cardiac dysfunction in sepsis might be different from that of myocardial ischemia. For example, a clinical study demonstrated that coronary flow in patients with septic shock is similar to or higher than that in patients without septic shock [20]. Conversely, many studies have reported that chemical mediators, such as endotoxins, cytokines, and nitric oxide (NO), induced from inducible NO synthase (iNOS) contribute to metabolic disorder, mitochondrial dysfunction, and downregulation of $\beta$ ARs. In particular, the systemic inflammatory response to chemical mediators impairs the ability of cardiac energy metabolism to produce adenosine triphosphate (ATP) in the heart, leading to cardiac dysfunction. In addition, the functional reversibility in SICM might depend on the change in cardiac ATP.

This review focuses on the current knowledge of metabolic alteration in sepsis, especially the dysregulation of cardiac metabolism.

\section{Energy Metabolism in the Heart}

\subsection{Fatty Acid Metabolism}

The main source of cardiac energy is fatty acids (FAs). Almost 70\% of ATP production depends on FA oxidation. FAs in serum are transported into cells via cell surface receptors, such as a cluster of differentiation 36 (CD36) or fatty acid-binding protein (FABP) and are converted into long-chain fatty acyl-coenzyme A (fatty acyl CoA) via long-chain acyl CoA synthetases in the cytoplasm. The long-chain fatty acyl CoA is transported into mitochondria via carnitine palmitoyltransferase (CPT)-1, and $\beta$-oxidation is performed to produce acetyl-CoA.

Peroxisome proliferator-activated receptors (PPARs) play important roles in cell metabolism. Mammals have three subtypes, PPAR- $\alpha$, PPAR- $\delta(\beta)$, and PPAR- $\gamma$. PPAR- $\alpha$, highly distributed in the liver and skeletal muscle, promotes the uptake and effective utilization of FAs [21]. PPAR- $\gamma$ is expressed in adipose tissues and regulates FA synthesis and lipid storage. Interestingly, in the reduction of FAO, PPAR- $\gamma$ promotes glucose metabolism. PPAR- $\delta(\beta)$ is also known to regulate lipid and glucose metabolism in the heart $[22,23]$.

\subsection{Glucose Oxidation}

Glucose metabolism contributes to ATP production in the decrease of FAO under stress conditions. Glucose transporter 4 (GLUT4) is the most important glucose transporter. The imported glucose is changed into glucose-6-phosphate (G-6-P) and enters various metabolic pathways, such as glycolysis, the pentose phosphate pathway (PPP), and the hexosamine biosynthetic pathway (HBP) [24]. G-6-P is converted to pyruvate in glycolysis, which is utilized to form alanine or lactate in the cytosol. Pyruvate is converted to acetylCoA in the mitochondria by pyruvate dehydrogenase and enters the tricarboxylic acid (TCA) cycle for ATP production.

\subsection{Ketone Metabolism}

Ketone bodies consist of acetoacetate, $\beta$-hydroxybutyric acid (B-OHB), and acetone, produced from plasma FAs in the liver. In general, ketone bodies are minimally consumed for cardiac energy in non-fasting conditions [25], whereas they contribute largely to energy metabolism in the state of stress or starvation.

Circulating ketone bodies enter cells via monocarboxylate transporters (MCTs) for ketone oxidation. B-OHB is oxidized to acetoacetate by B-OHB dehydrogenase 1 (BDH1) in mitochondria. Acetoacetate is converted to acetoacetyl-CoA by exchanging CoA between succinyl-CoA and acetoacetate by succinyl-CoA:3 ketoacid-CoA transferase (SCOT). Acetoacetyl-CoA then undergoes a thiolysis reaction of acetyl-CoA acetyltransferase 1 (ACAT1), converting acetoacetyl-CoA into acetyl-CoA, which enters the TCA cycle to produce ATP [26]. 


\subsection{Amino Acid Metabolism}

The most abundant group of essential amino acids consists of some branched-chain amino acids, including leucine, isoleucine, and valine. Amino acids are transported into cells via amino acid transporters and degraded into acetyl-CoA and succinyl-CoA by amino acid catabolic enzymes, such as branched-chain amino acid transaminases and branchedchain alpha-keto acid dehydrogenase (BCKD). Acetyl-CoA and succinyl-CoA enter the TCA cycle for ATP production [27]. In addition, amino acids activate the mammalian target of rapamycin complex 1 (mTORC1) [28,29].

\subsection{Mitochondrial Metabolism}

Mitochondria produce $95 \%$ of the ATP of cells [30]. ATP supply is based on mitochondrial oxidative phosphorylation (OXPHOS), and four electron transport chain complexes (I, II, III, and IV) and transporters (ubiquinone and cytochrome C) involve the transportation of electrons from the TCA cycle for ATP production. In addition, mitochondria play an important role in calcium signaling. The calcium concentration increase in mitochondria contributes to NADH upregulation [31,32] and ATP production [33].

\section{Metabolic Alternation in Sepsis}

Since Parrillo et al. found a circulating myocardial depressor in the serum of patients with sepsis in 1985 [34], the cardiac depressors have been identified as lipopolysaccharides (LPS), cytokines (interleukin (IL)-1b, tumor necrosis factor- $\alpha$ (TNF- $\alpha$ ), and IL-6) [35-37], NO synthase (dysregulation of NO synthase (NOS)) [38-40], and reactive oxygen species (ROS) [41,42]. In septic conditions, such massive proinflammatory mediators induce systemic and cellular metabolic alternations. In particular, this hypermetabolism in sepsis is characterized by an overall catabolic state, leading to the breakdown of carbohydrate, lipid, and protein stores [43]. In this section, we will outline the different metabolic pathways of the myocardium in sepsis (Figure 1).

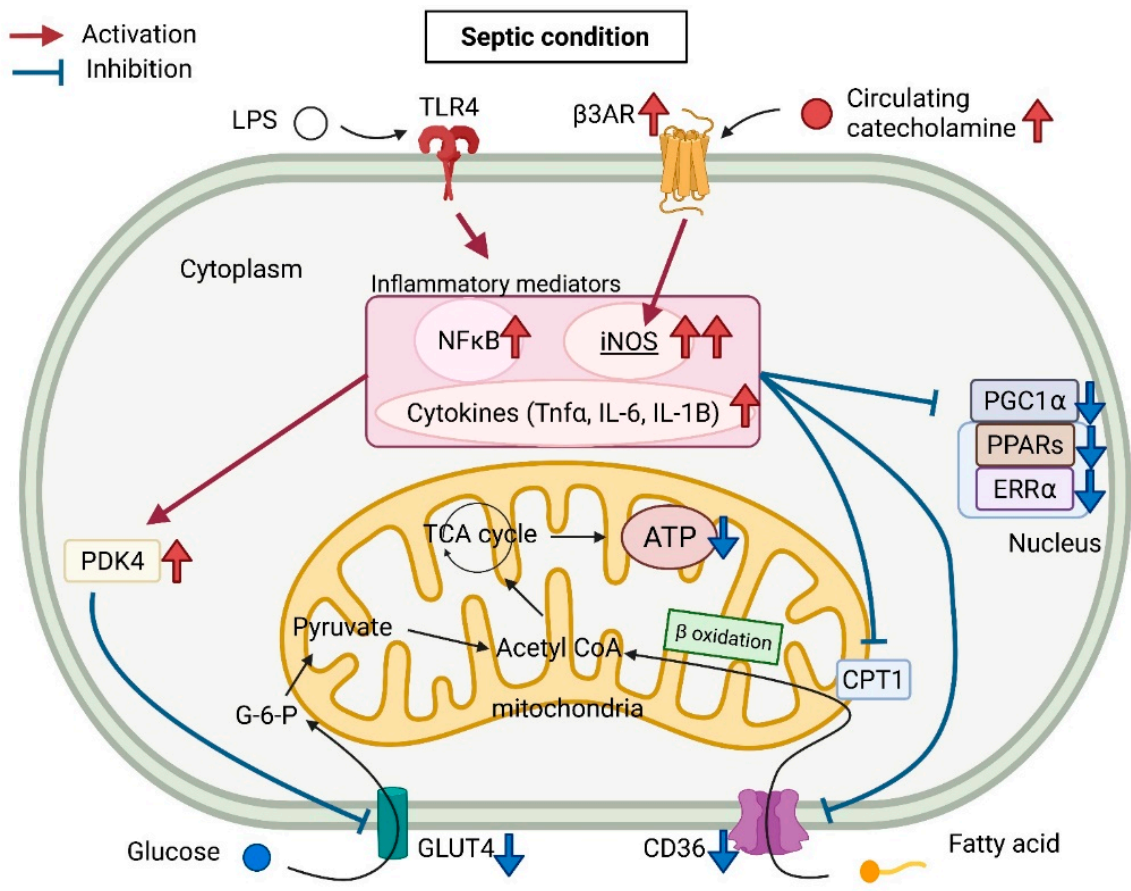

Figure 1. Schematic representation of myocardial metabolism in a septic condition.

\subsection{Lipid Metabolism in Sepsis}

As discussed before, lipid metabolism is the major source of ATP production. During sepsis, most patients are starving and need energy from lipid mobilization and oxidation $[44,45]$. Increased lipolysis in adipose tissue, the largest energy supplier in the body, 
converts triglycerides into FAs and glycerol, releasing them into the bloodstream to compensate for energy [46]. Free FAs enter peripheral organs for $\beta$ oxidation, producing ATP. However, the inflammatory response in sepsis dysregulates various genes associated with lipid metabolism. For example, LPS is reported to reduce PPAR $\alpha$ and PGC1 $\alpha$, which regulate the $\beta$ oxidation pathway [47]. In addition, the dysregulation of CD36 and CPT1 induces a deficiency of FA transportation, leading to impaired FAO [48-50]. In particular, decreased CPT1 prevents FAs from entering mitochondria. This situation leads to the accumulation of lipids into the cells, resulting in "lipotoxicity" which causes organ dysfunction.

The association between cardiac lipid accumulation and heart failure in humans was reported long ago. For example, Sharma et al. reported intramyocardial triacylglycerol (TAG) accumulation in patients with heart failure and its transcriptional profile using an animal model of lipotoxicity and contractile dysfunction [51]. Further evidence of lipid accumulation was found in heart samples from patients with severe chronic heart failure underdoing heart transplantation [52].

Lipid accumulation is associated with the cellular apoptotic mechanism [53,54], generation of ROS [55,56], ER stress, and cell death [57], which can lead to heart failure, per se. Although the mechanism of lipid accumulation has not been fully elucidated, lipid accumulation in heart failure underlies a metabolic disorder, especially impaired FAO. We reported a recovery time gap between the expression of CD36 and CPT1 in LPS-induced septic hearts [50]. This time gap leads to the imbalance of FA demand-supply between the cytoplasm and mitochondria and may cause lipid accumulation in the cytoplasm. In addition, the accumulation of fat has been identified in the liver, kidney, and heart muscle in patients with sepsis [58-60]. We also observed lipid accumulation in the cardiac tissue of endotoxin model mice. Intriguingly, many lipid droplets were observed around mitochondria in the myocardium $12 \mathrm{~h}$ after LPS injection, indicating cardiac dysfunction, but not at $24 \mathrm{~h}$. This suggests a strong relationship between lipid dysregulation and reversible cardiac function.

\subsection{Glucose Metabolism in Sepsis}

Glucose metabolism is also impaired in sepsis. The common characteristic symptom of patients with sepsis is hyperglycemia. Hyperglycemia is a result of the impaired balance between glycolysis and gluconeogenesis, increased insulin resistance, and dysregulation of glucose metabolism. However, hyperglycemia is partly desirable for the immune system. For example, glucose uptake in leukocytes is independent of insulin [61], and activated immune cells depend mainly on energy from aerobic glycolysis [62]. In general, ischemic heart failure increases glycolysis activity to compensate ATP instead of decreased FAO. In the state of hypoxia, aerobic glycolysis synthesizes ATP quickly, despite the ineffectiveness of ATP production. Moreover, glycolysis provides substrates for the synthesis of amino acids, lipids, and nucleotides. At the same time, SICM is reported to decrease not only FAO but also glycolysis. Some animal researchers reported decreased GLUT4 and increased pyruvate dehydrogenase lipoamide kinase isozyme (PDK)-4 in LPS-induced septic hearts [48-50]. PDK-4 is an important regulator of FAO and glucose metabolism. PDK-4 negatively regulates GLUT4 to increase FAO [63] and positively regulates PPAR $\alpha$ [64].

Intriguingly, Umbarawan et al. reported the accumulation of glycogen in LPS-induced septic hearts [65]. This finding suggests that the septic heart suppresses not only glycolysis and glucose oxidation but also glycogenolysis.

Insulin resistance is also one of the characteristic symptoms of sepsis [66]. In addition, various cytokine effects cause insulin resistance, the release of hyper catecholamine, increased counter-regulatory hormones in plasma, and activation of the sympathetic nervous system [67]. Furthermore, impaired insulin sensitivity of peripheral tissues shifts their metabolism toward lipolysis and proteolysis [68]. 


\subsection{Ketone Metabolism}

Many researchers have investigated FA and glucose utilization, whereas the knowledge about other nutrients, such as ketone bodies and amino acids, is relatively limited. Fasting conditions, such as sepsis, contribute to systemic hypercatabolism accompanied by increased lipolysis and ketogenesis [69]. Prolonged fasting results in hypoglycemia and promotes ketogenesis in the mitochondria of liver cells. Under limited glucose availability, ketone bodies become an important energy substrate for the brain and skeletal muscles. In addition, this ketogenesis contributes to an important role in biological defense because ketone bodies confer resistance to ROS [70]. Recently, ketone metabolism in heart failure has become known as an alternative fuel that compensates for cardiac energy homeostasis. A mouse model with advanced heart failure induced by TAC and coronary artery ligation demonstrated increased BDH1 expression accomplished by the increased expression of ketone body transporters (MCT1 and MCT2) and increased ${ }^{13} \mathrm{C}-\beta$-hydroxybutyrate (BHB) utilization based on nuclear magnetic resonance studies [71]. In another report, cardiacspecific BDH1 overexpression in TAC-induced heart failure prevented cardiac remodeling and DNA damage from pressure overloaded stress [71]. Moreover, a clinical study using nondiabetic, nonischemic heart samples of patients at the time of heart transplantation or left ventricular assist device implantation demonstrated an increased abundance of ketogenic $\beta$-hydroxybutyryl CoA and increased myocardial utilization of BHB while reducing intermediate and anaplerotic acyl CoA species for the Krebs cycle [72]. Conversely, ketone metabolism in SICM remains elusive. Umbarawan et al. reported that hepatic ketogenesis and cardiac ketolysis would be suppressed by LPS injection in mice lacking fatty acid-binding protein 4 (FABP4) and FABP5 (DKO mice) [65], which are important FA transporters. In their report, the expression of genes related to ketone body production in the liver and 3-oxoacid CoA-transfer (SCOT), required for ketone body degradation in the heart, was significantly decreased in both DKO and wild-type mice. This suggests that ketone metabolism in the heart is also impaired in SICM.

\subsection{Amino Acid Metabolism in Sepsis}

Amino acids are crucial nutrients for cellular homeostasis. According to clinical research, patients lost $13 \%$ of total body protein and $70 \%$ of the lost proteins from skeletal muscles during sepsis [73]. Sepsis activates proteolysis, the trimming process from proteins into smaller polypeptides and amino acids, in skeletal muscles [74,75]. Although the signaling that induces proteolysis in sepsis is poorly understood, the catabolism of skeletal muscle is necessary to support hepatic gluconeogenesis and protein synthesis. The major reason for increased proteolysis in sepsis is the urgent need for amino acids in the liver to maintain the acute phase response, thus reconstructing energy-abundant molecules [76]. For example, branched-chain amino acids (BCAAs) accept the ketone group of pyruvate and glutamate, which form glutamine and alanine. Glutamine is an important precursor for peptide and protein synthesis, supporting cytokine production. It is also required for purines and pyrimidines to form nucleotide acids for immune cells to increase [77-79]. Alanine is transported to the liver and enters the TCA cycle. In addition, essential amino acids are associated with sepsis. Arginine, one of the essential amino acids, is converted into nitric oxide by nitric oxide synthase released from M1 macrophages [80].

Thus, essential amino acids and BCAAs have important roles in maintaining internal homeostasis, including heart function, and they are expressed at high levels in healthy hearts. However, heart failure is known to show abnormal amino acid metabolism. On transcriptome analysis, some genes that regulate the BCAA catabolic pathway were significantly reduced and demonstrated BACC catabolic deficiency in pressure overload-induced mouse failing hearts and human dilated cardiomyopathy [81]. Another report observed dynamic changes in BCKD activity in a mouse heart post myocardial infarction (MI). This study also reported that BCAA catabolic activity is significantly decreased 1 week after MI [82]. Likewise, other studies using the sepsis animal model reported an abnormality of amino acid metabolism. In the mouse cecum ligated puncture (CLP) model, amino acid 
uptake was reduced by $90 \%$ in the heart at $16 \mathrm{~h}$ post CLP [82]. Another in vivo study found that metabolic changes in the rat heart of a CLP model showed a $28 \%$ decrease in alanine and a $31 \%$ decrease in glutamate [83], suggesting that sepsis-induced cardiac dysfunction accompanies impaired amino acid metabolism.

\subsection{Mitochondrial Metabolism in Sepsis}

Mitochondrial dysfunction has been discussed as a critical mechanism of organ failure in sepsis [84-86]. Mitochondria are involved in cellular homeostasis systems, such as the cell death pathway, calcium adjustment, redox signaling, and steroidogenesis, including the energy source of cells [87-90]. During sepsis, the capacity of tissues to utilize oxygen from the blood is reduced despite the normal consumption level of oxygen in tissues [91,92], and excessive ROS are generated from the process of ATP production in mitochondria. Increased ROS in the mitochondrial matrix decreases the efficiency of OXPHOS and leads to reduced ATP synthesis $[93,94]$. Furthermore, the mechanism of NO production contributes to ROS formation in sepsis. Mitochondria produce NO via mitochondrial NO synthase (mtNOS). This pathway regulates the mitochondrial respiratory chain by inhibition of cytochrome c oxidase [95]. In addition to mtNOS, inducible NOS (iNOS) is generated by various cells and organs, including cardiac tissues $[59,96,97]$. Although NO has a protective role in maintaining health [98], the excess production of NO generated by iNOS induces vasodilation, decreases cardiac contractility, blunts vascular reactivity to catecholamines, and causes mitochondrial dysfunction.

Cell stress brings about changes in mitochondrial oxygen consumption and OXPHOS. Several studies have reported decreased state 3 respiration, defined as ADP-stimulated respiration, and decreased mitochondrial OXPHOS complexes [50,99] in the septic heart. Decreased state 3 respiration induces a decreased respiratory control ratio, and OXPHOS inactivity decreases the mitochondrial transmembrane potential for the maintenance of energy health [100].

Dysregulation in intracellular calcium homeostasis has also been discussed in sepsisinduced cardiac dysfunction. A literature review showed that cardiac dysfunction in sepsis is associated with the dysregulation of various intracellular $\mathrm{Ca}^{2+}$ transporters, which is caused by the inhibition of L-type $\mathrm{Ca}^{2+}$ channels, sarcoplasmic (SR) $\mathrm{Ca}^{2+}$ ATPase (SERCA), RyR Ca ${ }^{2+}$ leak, and decreased sensitivity in myofilament $\mathrm{Ca}^{2+}$ channels [101]. This dysregulation of $\mathrm{Ca}^{2+}$ homeostasis causes decreased uptake of $\mathrm{Ca}^{2+}$ and increased $\mathrm{Ca}^{2+}$ leakage from SR, resulting in mitochondrial $\mathrm{Ca}^{2+}$ overload, leading to mitochondrial dysfunction.

In addition, the functional impairment of myocardial mitochondria is accompanied by structural abnormalities, such as mitochondrial deformation, a decrease in the number of mitochondria, and cristae derangement [102,103]. Despite the limited evidence, some clinical studies reported that patients with sepsis have hydropic mitochondria and damage to cristae [102,103]. Furthermore, many studies confirmed mitochondrial abnormalities in experimental animal sepsis models [97,104-109]. In contrast, some studies reported mitochondrial dysfunction without abnormalities of mitochondria [110-112]. The inconsistent results may depend on the severity of sepsis, the time course of sepsis, and the sepsis model, suggesting that morphological damage to cardiac mitochondria is not a requisite for cardiac function.

\section{Therapeutic Strategies to Metabolism in SICM}

As sepsis is a time-dependent disease, the prompt diagnosis and treatments of sepsis are required. However, even in septic shock, fundamental sepsis therapy is fluid resuscitation with vasopressors and antibiotics. Despite advances in medicine, there are no effective treatments for SICM.

Recently, $\beta$ AR blockers have attracted unprecedented attention as a treatment for severe sepsis. Originally, $\beta$ AR blockers were widely prescribed for patients with chronic heart failure caused by ischemia, various types of cardiomyopathy or arrhythmia. 
Overstimulating catecholamines in severe sepsis may play a critical role in the onset of SICM by calcium overload and the downregulation of $\beta$ AR signaling and $\beta$ ARs $[7,113,114]$. Therefore, the therapeutic strategy to prevent overstimulation of sympathetic nerves could be reasonable. Recent studies have shown that $\beta$ AR blockade therapy for sepsis reduces the incidence of new arrhythmias, prevents SICM, and even improves mortality [115-119].

The $\beta$ AR subtypes, $\beta 1 \mathrm{AR}$ and $\beta 2 \mathrm{AR}$, are both expressed in cardiomyocytes, of which $\beta 1 A R$ is the main receptor regulating the cardiac contractility response and heart rate [120]. $32 \mathrm{AR}$ is associated with glucose metabolism [121], the immune system [122], and inflammatory mediators $[123,124]$. Collectively, $\beta$ AR blockers affect the metabolism, immunology, and cardiac alternation induced by sepsis [125]. Notably, $\beta$ AR blockers are an attractive strategy for sepsis. $\beta 1 \mathrm{AR}$ blockers suppress excess catecholamine release, which prevents the hypercatabolic state in sepsis. Moreover, the block of $\beta 1 \mathrm{AR}$ decreases heart rate and prolongs the filling time of the left ventricle, thus increasing the stroke volume and maintaining cardiac output. Therefore, $\beta$ AR may add a novel line of conventional therapy for SICM.

Currently, we are focused on the effects of $\beta 3$ AR on cardiac metabolism in SICM and have reported that $\beta 3 \mathrm{AR}$ blockade improved cardiac dysfunction and mortality in mice with LPS-induced heart failure [50]. Most $\beta 3$ AR exists in fat cells and is associated with lipolysis, whereas there are a few $\beta 3 A R s$ in the heart. Interestingly, contrary to other $\beta A R$ subtypes, $\beta 3 A R$ increases in ischemic heart failure [126], and $\beta 3 A R$ stimulation improves cardiac function post MI via NOS regulation [127,128]. Against our expectation, however, blockade of $\beta 3$ AR significantly improved cardiac ATP and mortality, whereas $\beta 3 A R$ had the opposite result. Our findings demonstrated that (1) $\beta 3 A R$ is increased in septic hearts; (2) B3AR blockade preserves cardiac ATP through the improvement of FAO; (3) $\beta 3 \mathrm{AR}$ blockade prevents lipid accumulation in the myocardium; and (4) $\beta 3 \mathrm{AR}$ regulates iNOS. This research suggests that blockade of $\beta 3 A R$ improves FAO and ATP production in hearts by suppressing sepsis-induced iNOS generation. However, many researchers argue that B3AR activation is useful for improving cardiovascular pathogenesis [129]. As the pathogenesis of sepsis involves changes in immunity and metabolism over time, it may be important to identify the phases of the "metabolic switch."

In another study, Drosatos et al. reported that PPAR- $\gamma$ activation improved cardiac dysfunction and mortality in LPS-induced septic mice by preserving cardiac FAO and ATP. In contrast, PPAR- $\alpha$ activation failed [49]. Although cardiac metabolism in sepsis is complex, the metabolic approach can provide a new therapeutic strategy for SICM.

\section{Conclusions}

This review focuses on cardiac metabolism in sepsis. Sepsis is one of the leading causes of death, and SICM is associated with a worse outcome of sepsis. Although the mechanism of SICM has not been fully elucidated, many laboratory experiments and clinical data have accumulated evidence that ATP depletion by metabolic disorders contributes to SICM. In particular, the cardiac metabolism in sepsis is different from that in the ischemic heart, switching the energy pathway from FAO to glycolysis. As discussed above, SICM may not rely on any metabolic pathways because strong inflammation makes all ATP pathways dysregulated. Moreover, the imbalance between hypercatabolism to compensate energy and dysregulation of metabolic genes leads to detrimental effects, such as lipid accumulation. Therefore, when treating SICM, the focus should not only be on managing inflammation, but also on intervening in cardiac metabolism.

Author Contributions: S.K. drafted the paper and prepared the figures; M.O., the corresponding author, completed the paper. All authors have read and agreed to the published version of the manuscript.

Funding: There is no support from any funding.

Conflicts of Interest: There are no conflict of interest. 


\section{References}

1. Singer, M.; Deutschman, C.S.; Seymour, C.W.; Shankar-Hari, M.; Annane, D.; Bauer, M.; Bellomo, R.; Bernard, G.R.; Chiche, J.D.; Coopersmith, C.M.; et al. The Third International Consensus Definitions for Sepsis and Septic Shock (Sepsis-3). JAMA 2016, 315, 801-810. [CrossRef]

2. Fleischmann, C.; Scherag, A.; Adhikari, N.K.; Hartog, C.S.; Tsaganos, T.; Schlattmann, P.; Angus, D.C.; Reinhart, K. Assessment of Global Incidence and Mortality of Hospital-treated Sepsis. Current Estimates and Limitations. Am. J. Respir. Crit. Care Med. 2016, 193, 259-272. [CrossRef] [PubMed]

3. Beesley, S.J.; Weber, G.; Sarge, T.; Nikravan, S.; Grissom, C.K.; Lanspa, M.J.; Shahul, S.; Brown, S.M. Septic Cardiomyopathy. Crit. Care Med. 2018, 46, 625-634. [CrossRef] [PubMed]

4. L'Heureux, M.; Sternberg, M.; Brath, L.; Turlington, J.; Kashiouris, M.G. Sepsis-Induced Cardiomyopathy: A Comprehensive Review. Curr. Cardiol. Rep. 2020, 22, 35. [CrossRef]

5. Gulick, T.; Chung, M.K.; Pieper, S.J.; Lange, L.G.; Schreiner, G.F. Interleukin 1 and tumor necrosis factor inhibit cardiac myocyte beta-adrenergic responsiveness. Proc. Natl. Acad. Sci. USA 1989, 86, 6753-6757. [CrossRef] [PubMed]

6. Matsuda, N.; Hattori, Y.; Akaishi, Y.; Suzuki, Y.; Kemmotsu, O.; Gando, S. Impairment of cardiac beta-adrenoceptor cellular signaling by decreased expression of G(s alpha) in septic rabbits. Anesthesiology 2000, 93, 1465-1473. [CrossRef] [PubMed]

7. Rudiger, A.; Singer, M. Mechanisms of sepsis-induced cardiac dysfunction. Crit. Care Med. 2007, 35, 1599-1608. [CrossRef]

8. Waisbren, B.A. Bacteremia due to gram-negative bacilli other than the Salmonella; a clinical and therapeutic study. AMA Arch. Intern. Med. 1951, 88, 467-488. [CrossRef] [PubMed]

9. Parker, M.M.; Shelhamer, J.H.; Bacharach, S.L.; Green, M.V.; Natanson, C.; Frederick, T.M.; Damske, B.A.; Parrillo, J.E. Profound but reversible myocardial depression in patients with septic shock. Ann. Intern. Med. 1984, 100, 483-490. [CrossRef] [PubMed]

10. Parker, M.M.; Shelhamer, J.H.; Natanson, C.; Alling, D.W.; Parrillo, J.E. Serial cardiovascular variables in survivors and nonsurvivors of human septic shock: Heart rate as an early predictor of prognosis. Crit. Care Med. 1987, 15, 923-929. [CrossRef] [PubMed]

11. Charpentier, J.; Luyt, C.E.; Fulla, Y.; Vinsonneau, C.; Cariou, A.; Grabar, S.; Dhainaut, J.F.; Mira, J.P.; Chiche, J.D. Brain natriuretic peptide: A marker of myocardial dysfunction and prognosis during severe sepsis. Crit. Care Med. 2004, 32, 660-665. [CrossRef] [PubMed]

12. Parker, M.M.; McCarthy, K.E.; Ognibene, F.P.; Parrillo, J.E. Right ventricular dysfunction and dilatation, similar to left ventricular changes, characterize the cardiac depression of septic shock in humans. Chest 1990, 97, 126-131. [CrossRef] [PubMed]

13. Vieillard-Baron, A.; Caille, V.; Charron, C.; Belliard, G.; Page, B.; Jardin, F. Actual incidence of global left ventricular hypokinesia in adult septic shock. Crit. Care Med. 2008, 36, 1701-1706. [CrossRef] [PubMed]

14. Huang, S.J.; Nalos, M.; McLean, A.S. Is early ventricular dysfunction or dilatation associated with lower mortality rate in adult severe sepsis and septic shock? A meta-analysis. Crit. Care 2013, 17, R96. [CrossRef] [PubMed]

15. Sevilla Berrios, R.A.; O’Horo, J.C.; Velagapudi, V.; Pulido, J.N. Correlation of left ventricular systolic dysfunction determined by low ejection fraction and 30-day mortality in patients with severe sepsis and septic shock: A systematic review and meta-analysis. J. Crit. Care. 2014, 29, 495-499. [CrossRef] [PubMed]

16. Landesberg, G.; Gilon, D.; Meroz, Y.; Georgieva, M.; Levin, P.D.; Goodman, S.; Avidan, A.; Beeri, R.; Weissman, C.; Jaffe, A.S.; et al. Diastolic dysfunction and mortality in severe sepsis and septic shock. Eur. Heart. J. 2012, 33, 895-903. [CrossRef]

17. Palmieri, V.; Innocenti, F.; Guzzo, A.; Guerrini, E.; Vignaroli, D.; Pini, R. Left Ventricular Systolic Longitudinal Function as Predictor of Outcome in Patients with Sepsis. Circ. Cardiovasc. Imaging 2015, 8, e003865; discussion e003865. [CrossRef] [PubMed]

18. Sanfilippo, F.; Corredor, C.; Arcadipane, A.; Landesberg, G.; Vieillard-Baron, A.; Cecconi, M.; Fletcher, N. Tissue Doppler assessment of diastolic function and relationship with mortality in critically ill septic patients: A systematic review and metaanalysis. Br. J. Anaesth. 2017, 119, 583-594. [CrossRef] [PubMed]

19. Lanspa, M.J.; Cirulis, M.M.; Wiley, B.M.; Olsen, T.D.; Wilson, E.L.; Beesley, S.J.; Brown, S.M.; Hirshberg, E.L.; Grissom, C.K. Right Ventricular Dysfunction in Early Sepsis and Septic Shock. Chest 2021, 159, 1055-1063. [CrossRef] [PubMed]

20. Cunnion, R.E.; Schaer, G.L.; Parker, M.M.; Natanson, C.; Parrillo, J.E. The coronary circulation in human septic shock. Circulation 1986, 73, 637-644. [CrossRef] [PubMed]

21. Smith, S.A. Peroxisome proliferator-activated receptors and the regulation of mammalian lipid metabolism. Biochem. Soc. Trans. 2002, 30, 1086-1090. [CrossRef]

22. Nakamura, M.T.; Yudell, B.E.; Loor, J.J. Regulation of energy metabolism by long-chain fatty acids. Prog. Lipid Res. 2014, 53, 124-144. [CrossRef]

23. Wagner, K.D.; Wagner, N. Peroxisome proliferator-activated receptor beta/delta (PPARbeta/delta) acts as regulator of metabolism linked to multiple cellular functions. Pharmacol. Ther. 2010, 125, 423-435. [CrossRef]

24. Tran, D.H.; Wang, Z.V. Glucose Metabolism in Cardiac Hypertrophy and Heart Failure. J. Am. Heart Assoc. 2019 , 8, e012673. [CrossRef]

25. Ho, K.L.; Zhang, L.; Wagg, C.; Al Batran, R.; Gopal, K.; Levasseur, J.; Leone, T.; Dyck, J.R.B.; Ussher, J.R.; Muoio, D.M.; et al. Increased ketone body oxidation provides additional energy for the failing heart without improving cardiac efficiency. Cardiovasc. Res. 2019, 115, 1606-1616. [CrossRef]

26. Selvaraj, S.; Kelly, D.P.; Margulies, K.B. Implications of Altered Ketone Metabolism and Therapeutic Ketosis in Heart Failure. Circulation 2020, 141, 1800-1812. [CrossRef] 
27. D’Antona, G.; Ragni, M.; Cardile, A.; Tedesco, L.; Dossena, M.; Bruttini, F.; Caliaro, F.; Corsetti, G.; Bottinelli, R.; Carruba, M.O.; et al. Branched-chain amino acid supplementation promotes survival and supports cardiac and skeletal muscle mitochondrial biogenesis in middle-aged mice. Cell Metab. 2010, 12, 362-372. [CrossRef]

28. Rabanal-Ruiz, Y.; Otten, E.G.; Korolchuk, V.I. mTORC1 as the main gateway to autophagy. Essays Biochem. 2017, 61, 565-584. [CrossRef]

29. Linke, M.; Fritsch, S.D.; Sukhbaatar, N.; Hengstschläger, M.; Weichhart, T. mTORC1 and mTORC2 as regulators of cell metabolism in immunity. FEBS Lett. 2017, 591, 3089-3103. [CrossRef]

30. Moriyama, S.; Okamoto, K.; Tabira, Y.; Kikuta, K.; Kukita, I.; Hamaguchi, M.; Kitamura, N. Evaluation of oxygen consumption and resting energy expenditure in critically ill patients with systemic inflammatory response syndrome. Crit. Care Med. 1999, 27, 2133-2136. [CrossRef]

31. Rizzuto, R.; Bastianutto, C.; Brini, M.; Murgia, M.; Pozzan, T. Mitochondrial Ca ${ }^{2+}$ homeostasis in intact cells. J. Cell Biol. 1994, 126, 1183-1194. [CrossRef]

32. Hajnóczky, G.; Robb-Gaspers, L.D.; Seitz, M.B.; Thomas, A.P. Decoding of cytosolic calcium oscillations in the mitochondria. Cell 1995, 82, 415-424. [CrossRef]

33. Jouaville, L.S.; Pinton, P.; Bastianutto, C.; Rutter, G.A.; Rizzuto, R. Regulation of mitochondrial ATP synthesis by calcium: Evidence for a long-term metabolic priming. Proc. Natl. Acad. Sci. USA 1999, 96, 13807-13812. [CrossRef]

34. Parrillo, J.E.; Burch, C.; Shelhamer, J.H.; Parker, M.M.; Natanson, C.; Schuette, W. A circulating myocardial depressant substance in humans with septic shock. Septic shock patients with a reduced ejection fraction have a circulating factor that depresses in vitro myocardial cell performance. J. Clin. Investig. 1985, 76, 1539-1553. [CrossRef]

35. Kumar, A.; Thota, V.; Dee, L.; Olson, J.; Uretz, E.; Parrillo, J.E. Tumor necrosis factor alpha and interleukin 1beta are responsible for in vitro myocardial cell depression induced by human septic shock serum. J. Exp. Med. 1996, 183, 949-958. [CrossRef]

36. Pathan, N.; Franklin, J.L.; Eleftherohorinou, H.; Wright, V.J.; Hemingway, C.A.; Waddell, S.J.; Griffiths, M.; Dennis, J.L.; Relman, D.A.; Harding, S.E.; et al. Myocardial depressant effects of interleukin 6 in meningococcal sepsis are regulated by p38 mitogenactivated protein kinase. Crit. Care Med. 2011, 39, 1692-1711. [CrossRef] [PubMed]

37. Cain, B.S.; Meldrum, D.R.; Dinarello, C.A.; Meng, X.; Joo, K.S.; Banerjee, A.; Harken, A.H. Tumor necrosis factor-alpha and interleukin-1beta synergistically depress human myocardial function. Crit. Care Med. 1999, 27, 1309-1318. [CrossRef]

38. Kumar, A.; Brar, R.; Wang, P.; Dee, L.; Skorupa, G.; Khadour, F.; Schulz, R.; Parrillo, J.E. Role of nitric oxide and cGMP in human septic serum-induced depression of cardiac myocyte contractility. Am. J. Physiol. 1999, 276, R265-R276. [CrossRef]

39. Schulz, R.; Nava, E.; Moncada, S. Induction and potential biological relevance of a $\mathrm{Ca}(2+)$-independent nitric oxide synthase in the myocardium. Br. J. Pharmacol. 1992, 105, 575-580. [CrossRef]

40. Brady, A.J.; Poole-Wilson, P.A.; Harding, S.E.; Warren, J.B. Nitric oxide production within cardiac myocytes reduces their contractility in endotoxemia. Am. J. Physiol. 1992, 263, H1963-H1966. [CrossRef]

41. Ferdinandy, P.; Danial, H.; Ambrus, I.; Rothery, R.A.; Schulz, R. Peroxynitrite is a major contributor to cytokine-induced myocardial contractile failure. Circ. Res. 2000, 87, 241-247. [CrossRef]

42. Haileselassie, B.; Su, E.; Pozios, I.; Niño, D.F.; Liu, H.; Lu, D.Y.; Ventoulis, I.; Fulton, W.B.; Sodhi, C.P.; Hackam, D.; et al. Myocardial oxidative stress correlates with left ventricular dysfunction on strain echocardiography in a rodent model of sepsis. Intensive Care Med. Exp. 2017, 5, 21. [CrossRef]

43. Michie, H.R. Metabolism of sepsis and multiple organ failure. World. J. Surg. 1996, 20, 460-464. [CrossRef]

44. Nordenström, J.; Carpentier, Y.A.; Askanazi, J.; Robin, A.P.; Elwyn, D.H.; Hensle, T.W.; Kinney, J.M. Metabolic utilization of intravenous fat emulsion during total parenteral nutrition. Ann. Surg. 1982, 196, 221-231. [CrossRef] [PubMed]

45. Wolowczuk, I.; Verwaerde, C.; Viltart, O.; Delanoye, A.; Delacre, M.; Pot, B.; Grangette, C. Feeding our immune system: Impact on metabolism. Clin. Dev. Immunol. 2008, 2008, 639803. [CrossRef]

46. Rittig, N.; Bach, E.; Thomsen, H.H.; Pedersen, S.B.; Nielsen, T.S.; Jørgensen, J.O.; Jessen, N.; Møller, N. Regulation of Lipolysis and Adipose Tissue Signaling during Acute Endotoxin-Induced Inflammation: A Human Randomized Crossover Trial. PLoS ONE 2016, 11, e0162167. [CrossRef]

47. Hiukka, A.; Maranghi, M.; Matikainen, N.; Taskinen, M.R. PPARalpha: An emerging therapeutic target in diabetic microvascular damage. Nat. Rev. Endocrinol. 2010, 6, 454-463. [CrossRef] [PubMed]

48. Drosatos, K.; Drosatos-Tampakaki, Z.; Khan, R.; Homma, S.; Schulze, P.C.; Zannis, V.I.; Goldberg, I.J. Inhibition of c-Jun-Nterminal kinase increases cardiac peroxisome proliferator-activated receptor alpha expression and fatty acid oxidation and prevents lipopolysaccharide-induced heart dysfunction. J. Biol. Chem. 2011, 286, 36331-36339. [CrossRef] [PubMed]

49. Drosatos, K.; Khan, R.S.; Trent, C.M.; Jiang, H.; Son, N.H.; Blaner, W.S.; Homma, S.; Schulze, P.C.; Goldberg, I.J. Peroxisome proliferator-activated receptor- $\gamma$ activation prevents sepsis-related cardiac dysfunction and mortality in mice. Circ. Heart Fail. 2013, 6, 550-562. [CrossRef]

50. Kawaguchi, S.; Okada, M.; Ijiri, E.; Koga, D.; Watanabe, T.; Hayashi, K.; Kashiwagi, Y.; Fujita, S.; Hasebe, N. $\beta(3)$-Adrenergic receptor blockade reduces mortality in endotoxin-induced heart failure by suppressing induced nitric oxide synthase and saving cardiac metabolism. Am. J. Physiol. Heart Circ. Physiol. 2020, 318, H283-H294. [CrossRef]

51. Sharma, S.; Adrogue, J.V.; Golfman, L.; Uray, I.; Lemm, J.; Youker, K.; Noon, G.P.; Frazier, O.H.; Taegtmeyer, H. Intramyocardial lipid accumulation in the failing human heart resembles the lipotoxic rat heart. FASEB J. 2004, 18, 1692-1700. [CrossRef] [PubMed] 
52. Chokshi, A.; Drosatos, K.; Cheema, F.H.; Ji, R.; Khawaja, T.; Yu, S.; Kato, T.; Khan, R.; Takayama, H.; Knöll, R.; et al. Ventricular assist device implantation corrects myocardial lipotoxicity, reverses insulin resistance, and normalizes cardiac metabolism in patients with advanced heart failure. Circulation 2012, 125, 2844-2853. [CrossRef] [PubMed]

53. Hickson-Bick, D.L.; Buja, L.M.; McMillin, J.B. Palmitate-mediated alterations in the fatty acid metabolism of rat neonatal cardiac myocytes. J. Mol. Cell. Cardiol. 2000, 32, 511-519. [CrossRef]

54. Sparagna, G.C.; Hickson-Bick, D.L.; Buja, L.M.; McMillin, J.B. A metabolic role for mitochondria in palmitate-induced cardiac myocyte apoptosis. Am. J. Physiol. Heart Circ. Physiol. 2000, 279, H2124-H2132. [CrossRef]

55. Listenberger, L.L.; Ory, D.S.; Schaffer, J.E. Palmitate-induced apoptosis can occur through a ceramide-independent pathway. J. Biol. Chem. 2001, 276, 14890-14895. [CrossRef] [PubMed]

56. Du, X.; Edelstein, D.; Obici, S.; Higham, N.; Zou, M.H.; Brownlee, M. Insulin resistance reduces arterial prostacyclin synthase and eNOS activities by increasing endothelial fatty acid oxidation. J. Clin. Investig. 2006, 116, 1071-1080. [CrossRef]

57. Borradaile, N.M.; Buhman, K.K.; Listenberger, L.L.; Magee, C.J.; Morimoto, E.T.; Ory, D.S.; Schaffer, J.E. A critical role for eukaryotic elongation factor 1A-1 in lipotoxic cell death. Mol. Biol. Cell 2006, 17, 770-778. [CrossRef] [PubMed]

58. Zager, R.A.; Johnson, A.C.; Hanson, S.Y. Renal tubular triglyercide accumulation following endotoxic, toxic, and ischemic injury. Kidney. Int. 2005, 67, 111-121. [CrossRef]

59. Rossi, M.A.; Celes, M.R.; Prado, C.M.; Saggioro, F.P. Myocardial structural changes in long-term human severe sepsis/septic shock may be responsible for cardiac dysfunction. Shock 2007, 27, 10-18. [CrossRef] [PubMed]

60. Koskinas, J.; Gomatos, I.P.; Tiniakos, D.G.; Memos, N.; Boutsikou, M.; Garatzioti, A.; Archimandritis, A.; Betrosian, A. Liver histology in ICU patients dying from sepsis: A clinico-pathological study. World J. Gastroenterol. 2008, 14, 1389-1393. [CrossRef]

61. Marik, P.E.; Bellomo, R. Stress hyperglycemia: An essential survival response! Crit. Care 2013, 17, 305. [CrossRef]

62. Cheng, S.C.; Scicluna, B.P.; Arts, R.J.; Gresnigt, M.S.; Lachmandas, E.; Giamarellos-Bourboulis, E.J.; Kox, M.; Manjeri, G.R.; Wagenaars, J.A.; Cremer, O.L.; et al. Broad defects in the energy metabolism of leukocytes underlie immunoparalysis in sepsis. Nat. Immunol. 2016, 17, 406-413. [CrossRef]

63. Pettersen, I.K.N.; Tusubira, D.; Ashrafi, H.; Dyrstad, S.E.; Hansen, L.; Liu, X.Z.; Nilsson, L.I.H.; Løvsletten, N.G.; Berge, K.; Wergedahl, H.; et al. Upregulated PDK4 expression is a sensitive marker of increased fatty acid oxidation. Mitochondrion 2019, 49, 97-110. [CrossRef]

64. Finck, B.N.; Lehman, J.J.; Leone, T.C.; Welch, M.J.; Bennett, M.J.; Kovacs, A.; Han, X.; Gross, R.W.; Kozak, R.; Lopaschuk, G.D.; et al. The cardiac phenotype induced by PPARalpha overexpression mimics that caused by diabetes mellitus. J. Clin. Investig. 2002, 109, 121-130. [CrossRef]

65. Umbarawan, Y.; Syamsunarno, M.; Obinata, H.; Yamaguchi, A.; Sunaga, H.; Matsui, H.; Hishiki, T.; Matsuura, T.; Koitabashi, N.; Obokata, M.; et al. Robust suppression of cardiac energy catabolism with marked accumulation of energy substrates during lipopolysaccharide-induced cardiac dysfunction in mice. Metabolism 2017, 77, 47-57. [CrossRef]

66. Carlson, G.L. Hunterian Lecture: Insulin resistance in human sepsis: Implications for the nutritional and metabolic care of the critically ill surgical patient. Ann. R. Coll. Surg. Engl. 2004, 86, 75-81. [CrossRef] [PubMed]

67. Singer, M.; De Santis, V.; Vitale, D.; Jeffcoate, W. Multiorgan failure is an adaptive, endocrine-mediated, metabolic response to overwhelming systemic inflammation. Lancet 2004, 364, 545-548. [CrossRef]

68. Andersen, S.K.; Gjedsted, J.; Christiansen, C.; Tønnesen, E. The roles of insulin and hyperglycemia in sepsis pathogenesis. J. Leukoc. Biol. 2004, 75, 413-421. [CrossRef] [PubMed]

69. Wang, A.; Huen, S.C.; Luan, H.H.; Yu, S.; Zhang, C.; Gallezot, J.D.; Booth, C.J.; Medzhitov, R. Opposing Effects of Fasting Metabolism on Tissue Tolerance in Bacterial and Viral Inflammation. Cell 2016, 166, 1512-1525. [CrossRef] [PubMed]

70. Shimazu, T.; Hirschey, M.D.; Newman, J.; He, W.; Shirakawa, K.; Le Moan, N.; Grueter, C.A.; Lim, H.; Saunders, L.R.; Stevens, R.D.; et al. Suppression of oxidative stress by $\beta$-hydroxybutyrate, an endogenous histone deacetylase inhibitor. Science 2013, 339, 211-214. [CrossRef]

71. Aubert, G.; Martin, O.J.; Horton, J.L.; Lai, L.; Vega, R.B.; Leone, T.C.; Koves, T.; Gardell, S.J.; Krüger, M.; Hoppel, C.L.; et al. The Failing Heart Relies on Ketone Bodies as a Fuel. Circulation 2016, 133, 698-705. [CrossRef]

72. Bedi, K.C., Jr.; Snyder, N.W.; Brandimarto, J.; Aziz, M.; Mesaros, C.; Worth, A.J.; Wang, L.L.; Javaheri, A.; Blair, I.A.; Margulies, K.B.; et al. Evidence for Intramyocardial Disruption of Lipid Metabolism and Increased Myocardial Ketone Utilization in Advanced Human Heart Failure. Circulation 2016, 133, 706-716. [CrossRef] [PubMed]

73. Plank, L.D.; Hill, G.L. Sequential metabolic changes following induction of systemic inflammatory response in patients with severe sepsis or major blunt trauma. World J. Surg. 2000, 24, 630-638. [CrossRef] [PubMed]

74. Lang, C.H.; Frost, R.A.; Nairn, A.C.; MacLean, D.A.; Vary, T.C. TNF-alpha impairs heart and skeletal muscle protein synthesis by altering translation initiation. Am. J. Physiol. Endocrinol. Metab. 2002, 282, E336-E347. [CrossRef] [PubMed]

75. Lang, C.H.; Frost, R.A.; Jefferson, L.S.; Kimball, S.R.; Vary, T.C. Endotoxin-induced decrease in muscle protein synthesis is associated with changes in eIF2B, eIF4E, and IGF-I. Am. J. Physiol. Endocrinol. Metab. 2000, 278, E1133-E1143. [CrossRef]

76. Hasselgren, P.O.; Pedersen, P.; Sax, H.C.; Warner, B.W.; Fischer, J.E. Current concepts of protein turnover and amino acid transport in liver and skeletal muscle during sepsis. Arch. Surg. 1988, 123, 992-999. [CrossRef]

77. Newsholme, E.A.; Parry-Billings, M. Properties of glutamine release from muscle and its importance for the immune system. $J$. Parenter. Enteral. Nutr. 1990, 14, 63s-67s. [CrossRef] 
78. Windmueller, H.G.; Spaeth, A.E. Respiratory fuels and nitrogen metabolism in vivo in small intestine of fed rats. Quantitative importance of glutamine, glutamate, and aspartate. J. Biol. Chem. 1980, 255, 107-112. [CrossRef]

79. Rohde, T.; Ullum, H.; Rasmussen, J.P.; Kristensen, J.H.; Newsholme, E.; Pedersen, B.K. Effects of glutamine on the immune system: Influence of muscular exercise and HIV infection. J. Appl. Physiol. 1995, 79, 146-150. [CrossRef]

80. Stuehr, D.J. Enzymes of the L-arginine to nitric oxide pathway. J. Nutr. 2004, 134, 2748S-2751S; discussion 2765S-2767S. [CrossRef]

81. Sun, H.; Olson, K.C.; Gao, C.; Prosdocimo, D.A.; Zhou, M.; Wang, Z.; Jeyaraj, D.; Youn, J.Y.; Ren, S.; Liu, Y.; et al. Catabolic Defect of Branched-Chain Amino Acids Promotes Heart Failure. Circulation 2016, 133, 2038-2049. [CrossRef] [PubMed]

82. Hasselgren, P.O.; James, J.H.; Fischer, J.E. Inhibited muscle amino acid uptake in sepsis. Ann. Surg. 1986, 203, 360-365. [CrossRef]

83. Hotchkiss, R.S.; Song, S.K.; Neil, J.J.; Chen, R.D.; Manchester, J.K.; Karl, I.E.; Lowry, O.H.; Ackerman, J.J. Sepsis does not impair tricarboxylic acid cycle in the heart. Am. J. Physiol. 1991, 260, C50-C57. [CrossRef] [PubMed]

84. Crouser, E.D. Mitochondrial dysfunction in septic shock and multiple organ dysfunction syndrome. Mitochondrion 2004, 4, 729-741. [CrossRef] [PubMed]

85. Brealey, D.; Singer, M. Mitochondrial Dysfunction in Sepsis. Curr. Infect. Dis. Rep. 2003, 5, 365-371. [CrossRef]

86. Lin, Y.; Xu, Y.; Zhang, Z. Sepsis-Induced Myocardial Dysfunction (SIMD): The Pathophysiological Mechanisms and Therapeutic Strategies Targeting Mitochondria. Inflammation 2020, 43, 1184-1200. [CrossRef]

87. Galluzzi, L.; Kepp, O.; Kroemer, G. Mitochondria: Master regulators of danger signalling. Nat. Rev. Mol. Cell. Biol. 2012, 13, 780-788. [CrossRef]

88. Osellame, L.D.; Blacker, T.S.; Duchen, M.R. Cellular and molecular mechanisms of mitochondrial function. Best. Pract. Res. Clin. Endocrinol. Metab. 2012, 26, 711-723. [CrossRef]

89. Papadopoulos, V.; Miller, W.L. Role of mitochondria in steroidogenesis. Best. Pract. Res. Clin. Endocrinol. Metab. 2012, 26, 771-790. [CrossRef]

90. Chinopoulos, C.; Adam-Vizi, V. Mitochondria as ATP consumers in cellular pathology. Biochim. Biophys. Acta. 2010, 1802, $221-227$. [CrossRef]

91. Fink, M.P. Cytopathic hypoxia and sepsis: Is mitochondrial dysfunction pathophysiologically important or just an epiphenomenon. Pediatr. Crit. Care Med. 2015, 16, 89-91. [CrossRef]

92. Suetrong, B.; Walley, K.R. Lactic Acidosis in Sepsis: It's Not All Anaerobic: Implications for Diagnosis and Management. Chest 2016, 149, 252-261. [CrossRef]

93. Chen, Y.R.; Zweier, J.L. Cardiac mitochondria and reactive oxygen species generation. Circ. Res. 2014, 114, 524-537. [CrossRef] [PubMed]

94. Brookes, P.S.; Yoon, Y.; Robotham, J.L.; Anders, M.W.; Sheu, S.S. Calcium, ATP, and ROS: A mitochondrial love-hate triangle. Am. J. Physiol. Cell Physiol. 2004, 287, C817-C833. [CrossRef]

95. Kanai, A.J.; Pearce, L.L.; Clemens, P.R.; Birder, L.A.; VanBibber, M.M.; Choi, S.Y.; de Groat, W.C.; Peterson, J. Identification of a neuronal nitric oxide synthase in isolated cardiac mitochondria using electrochemical detection. Proc. Natl. Acad. Sci. USA 2001, 98, 14126-14131. [CrossRef] [PubMed]

96. Rabuel, C.; Samuel, J.L.; Lortat-Jacob, B.; Marotte, F.; Lanone, S.; Keyser, C.; Lessana, A.; Payen, D.; Mebazaa, A. Activation of the ubiquitin proteolytic pathway in human septic heart and diaphragm. Cardiovasc. Pathol. 2010, 19, 158-164. [CrossRef]

97. Joshi, M.S.; Julian, M.W.; Huff, J.E.; Bauer, J.A.; Xia, Y.; Crouser, E.D. Calcineurin regulates myocardial function during acute endotoxemia. Am. J. Respir. Crit. Care Med. 2006, 173, 999-1007. [CrossRef] [PubMed]

98. Massion, P.B.; Feron, O.; Dessy, C.; Balligand, J.L. Nitric oxide and cardiac function: Ten years after, and continuing. Circ. Res. 2003, 93, 388-398. [CrossRef]

99. Kozlov, A.V.; Staniek, K.; Haindl, S.; Piskernik, C.; Ohlinger, W.; Gille, L.; Nohl, H.; Bahrami, S.; Redl, H. Different effects of endotoxic shock on the respiratory function of liver and heart mitochondria in rats. Am. J. Physiol. Gastrointest. Liver Physiol. 2006, 290, G543-G549. [CrossRef]

100. Zorova, L.D.; Popkov, V.A.; Plotnikov, E.Y.; Silachev, D.N.; Pevzner, I.B.; Jankauskas, S.S.; Babenko, V.A.; Zorov, S.D.; Balakireva, A.V.; Juhaszova, M.; et al. Mitochondrial membrane potential. Anal. Biochem. 2018, 552, 50-59. [CrossRef]

101. Hobai, I.A.; Edgecomb, J.; LaBarge, K.; Colucci, W.S. Dysregulation of intracellular calcium transporters in animal models of sepsis-induced cardiomyopathy. Shock 2015, 43, 3-15. [CrossRef] [PubMed]

102. Soriano, F.G.; Nogueira, A.C.; Caldini, E.G.; Lins, M.H.; Teixeira, A.C.; Cappi, S.B.; Lotufo, P.A.; Bernik, M.M.; Zsengellér, Z.; Chen, M.; et al. Potential role of poly (adenosine 5'-diphosphate-ribose) polymerase activation in the pathogenesis of myocardial contractile dysfunction associated with human septic shock. Crit. Care Med. 2006, 34, 1073-1079. [CrossRef] [PubMed]

103. Takasu, O.; Gaut, J.P.; Watanabe, E.; To, K.; Fagley, R.E.; Sato, B.; Jarman, S.; Efimov, I.R.; Janks, D.L.; Srivastava, A.; et al. Mechanisms of cardiac and renal dysfunction in patients dying of sepsis. Am. J. Respir. Crit. Care Med. 2013, 187, 509-517. [CrossRef]

104. Solomon, M.A.; Correa, R.; Alexander, H.R.; Koev, L.A.; Cobb, J.P.; Kim, D.K.; Roberts, W.C.; Quezado, Z.M.; Scholz, T.D.; Cunnion, R.E.; et al. Myocardial energy metabolism and morphology in a canine model of sepsis. Am. J. Physiol. 1994, 266, H757-H768. [CrossRef]

105. Watts, J.A.; Kline, J.A.; Thornton, L.R.; Grattan, R.M.; Brar, S.S. Metabolic dysfunction and depletion of mitochondria in hearts of septic rats. J. Mol. Cell. Cardiol. 2004, 36, 141-150. [CrossRef] 
106. Suliman, H.B.; Welty-Wolf, K.E.; Carraway, M.; Tatro, L.; Piantadosi, C.A. Lipopolysaccharide induces oxidative cardiac mitochondrial damage and biogenesis. Cardiovasc. Res. 2004, 64, 279-288. [CrossRef]

107. Smeding, L.; Leong-Poi, H.; Hu, P.; Shan, Y.; Haitsma, J.J.; Horvath, E.; Furmli, S.; Masoom, H.; Kuiper, J.W.; Slutsky, A.S.; et al. Salutary effect of resveratrol on sepsis-induced myocardial depression. Crit. Care Med. 2012, 40, 1896-1907. [CrossRef]

108. Vanasco, V.; Saez, T.; Magnani, N.D.; Pereyra, L.; Marchini, T.; Corach, A.; Vaccaro, M.I.; Corach, D.; Evelson, P.; Alvarez, S. Cardiac mitochondrial biogenesis in endotoxemia is not accompanied by mitochondrial function recovery. Free Radic. Biol. Med. 2014, 77, 1-9. [CrossRef]

109. Rudiger, A.; Dyson, A.; Felsmann, K.; Carré, J.E.; Taylor, V.; Hughes, S.; Clatworthy, I.; Protti, A.; Pellerin, D.; Lemm, J.; et al. Early functional and transcriptomic changes in the myocardium predict outcome in a long-term rat model of sepsis. Clin. Sci. 2013, 124, 391-401. [CrossRef]

110. Pinto, B.B.; Dyson, A.; Umbrello, M.; Carré, J.E.; Ritter, C.; Clatworthy, I.; Duchen, M.R.; Singer, M. Improved Survival in a Long-Term Rat Model of Sepsis Is Associated with Reduced Mitochondrial Calcium Uptake Despite Increased Energetic Demand. Crit. Care Med. 2017, 45, e840-e848. [CrossRef] [PubMed]

111. Smeding, L.; van der Laarse, W.J.; van Veelen, T.A.; Lamberts, R.R.; Niessen, H.W.; Kneyber, M.C.; Groeneveld, A.B.; Plötz, F.B. Early myocardial dysfunction is not caused by mitochondrial abnormalities in a rat model of peritonitis. J. Surg. Res. 2012, 176, 178-184. [CrossRef] [PubMed]

112. Standage, S.W.; Bennion, B.G.; Knowles, T.O.; Ledee, D.R.; Portman, M.A.; McGuire, J.K.; Liles, W.C.; Olson, A.K. PPAR $\alpha$ augments heart function and cardiac fatty acid oxidation in early experimental polymicrobial sepsis. Am. J. Physiol. Heart Circ. Physiol. 2017, 312, H239-H249. [CrossRef] [PubMed]

113. Hunter, J.D.; Doddi, M. Sepsis and the heart. Br. J. Anaesth. 2010, 104, 3-11. [CrossRef]

114. De Montmollin, E.; Aboab, J.; Mansart, A.; Annane, D. Bench-to-bedside review: Beta-adrenergic modulation in sepsis. Crit. Care 2009, 13, 230. [CrossRef] [PubMed]

115. Suzuki, T.; Morisaki, H.; Serita, R.; Yamamoto, M.; Kotake, Y.; Ishizaka, A.; Takeda, J. Infusion of the beta-adrenergic blocker esmolol attenuates myocardial dysfunction in septic rats. Crit. Care Med. 2005, 33, 2294-2301. [CrossRef] [PubMed]

116. Ackland, G.L.; Yao, S.T.; Rudiger, A.; Dyson, A.; Stidwill, R.; Poputnikov, D.; Singer, M.; Gourine, A.V. Cardioprotection, attenuated systemic inflammation, and survival benefit of beta1-adrenoceptor blockade in severe sepsis in rats. Crit. Care Med. 2010, 38, 388-394. [CrossRef]

117. Tan, K.; Harazim, M.; Tang, B.; McLean, A.; Nalos, M. The association between premorbid beta blocker exposure and mortality in sepsis-a systematic review. Crit. Care 2019, 23, 298. [CrossRef]

118. Tan, K.; Harazim, M.; Simpson, A.; Tan, Y.C.; Gunawan, G.; Robledo, K.P.; Whitehead, C.; Tang, B.; McLean, A.; Nalos, M. Association Between Premorbid Beta-Blocker Exposure and Sepsis Outcomes-The Beta-Blockers in European and Australian/American Septic Patients (BEAST) Study. Crit. Care Med. 2021, 49, 1493-1503. [CrossRef]

119. Kakihana, Y.; Nishida, O.; Taniguchi, T.; Okajima, M.; Morimatsu, H.; Ogura, H.; Yamada, Y.; Nagano, T.; Morishima, E.; Matsuda, N. Efficacy and safety of landiolol, an ultra-short-acting $\beta 1$-selective antagonist, for treatment of sepsis-related tachyarrhythmia (J-Land 3S): A multicentre, open-label, randomised controlled trial. Lancet Respir. Med. 2020, 8, 863-872. [CrossRef]

120. Brodde, O.E. Beta 1- and beta 2-adrenoceptors in the human heart: Properties, function, and alterations in chronic heart failure. Pharmacol. Rev. 1991, 43, 203-242.

121. Lang, C.H. Sepsis-induced insulin resistance in rats is mediated by a beta-adrenergic mechanism. Am. J. Physiol. 1992, 263, E703-E711. [CrossRef] [PubMed]

122. Tanner, M.A.; Maitz, C.A.; Grisanti, L.A. Immune cell $\beta(2)$-adrenergic receptors contribute to the development of heart failure. Am. J. Physiol. Heart Circ. Physiol. 2021, 321, H633-H649. [CrossRef]

123. Yin, F.; Wang, Y.Y.; Du, J.H.; Li, C.; Lu, Z.Z.; Han, C.; Zhang, Y.Y. Noncanonical cAMP pathway and p38 MAPK mediate beta2-adrenergic receptor-induced IL-6 production in neonatal mouse cardiac fibroblasts. J. Mol. Cell. Cardiol. 2006, 40, 384-393. [CrossRef] [PubMed]

124. Xu, Q.; Dalic, A.; Fang, L.; Kiriazis, H.; Ritchie, R.H.; Sim, K.; Gao, X.M.; Drummond, G.; Sarwar, M.; Zhang, Y.Y.; et al. Myocardial oxidative stress contributes to transgenic $\beta_{2}$-adrenoceptor activation-induced cardiomyopathy and heart failure. Br. J. Pharmacol. 2011, 162, 1012-1028. [CrossRef]

125. Novotny, N.M.; Lahm, T.; Markel, T.A.; Crisostomo, P.R.; Wang, M.; Wang, Y.; Ray, R.; Tan, J.; Al-Azzawi, D.; Meldrum, D.R. beta-Blockers in sepsis: Reexamining the evidence. Shock 2009, 31, 113-119. [CrossRef] [PubMed]

126. Cannavo, A.; Koch, W.J. Targeting $\beta 3$-Adrenergic Receptors in the Heart: Selective Agonism and $\beta$-Blockade. J. Cardiovasc. Pharmacol. 2017, 69, 71-78. [CrossRef]

127. Aragón, J.P.; Condit, M.E.; Bhushan, S.; Predmore, B.L.; Patel, S.S.; Grinsfelder, D.B.; Gundewar, S.; Jha, S.; Calvert, J.W.; Barouch, L.A.; et al. Beta3-adrenoreceptor stimulation ameliorates myocardial ischemia-reperfusion injury via endothelial nitric oxide synthase and neuronal nitric oxide synthase activation. J. Am. Coll. Cardiol. 2011, 58, 2683-2691. [CrossRef]

128. Niu, X.; Watts, V.L.; Cingolani, O.H.; Sivakumaran, V.; Leyton-Mange, J.S.; Ellis, C.L.; Miller, K.L.; Vandegaer, K.; Bedja, D.; Gabrielson, K.L.; et al. Cardioprotective effect of beta-3 adrenergic receptor agonism: Role of neuronal nitric oxide synthase. J. Am. Coll. Cardiol. 2012, 59, 1979-1987. [CrossRef]

129. Michel, L.Y.M.; Farah, C.; Balligand, J.L. The Beta3 Adrenergic Receptor in Healthy and Pathological Cardiovascular Tissues. Cells 2020, 9, 2584. [CrossRef] 